\title{
The stress-response proteins poly(ADP-ribose) polymerase and NF- $\kappa$ B protect against bile salt-induced apoptosis
}

\author{
Claire M. Payne ${ }^{1,3,7}$, Cara Crowley ${ }^{1}$, Delon Washo-Stultz ${ }^{1}$, \\ Margaret Briehl', Harris Bernstein ${ }^{1}$, Carol Bernstein ${ }^{1}$, \\ Shannon Beard ${ }^{4}$, Hana Holubec ${ }^{5}$ and James Warneke ${ }^{6}$ \\ ${ }^{1}$ Department of Microbiology and Immunology, College of Medicine, University \\ of Arizona, USA \\ 2 Department of Pathology, College of Medicine, University of Arizona, USA \\ ${ }^{3}$ Arizona Research Laboratories, Division of Biotechnology, University of \\ Arizona, USA \\ ${ }^{4}$ Xenometrix, Boulder, Colorado, USA \\ ${ }^{5}$ Arizona Cancer Center, Arizona Health Sciences Center, University of Arizona, \\ USA \\ ${ }^{6}$ Department of Surgery, College of Medicine, University of Arizona, USA \\ 7 corresponding author: Claire M. Payne, Ph.D., Department of Microbiology \\ and Immunology College of Medicine, University of Arizona, Tucson, \\ AZ 85724, USA; tel: +1 (520) 626-2870; fax: +1 (520) 626-2100; \\ email: cpayne@u.arizona.edu
}

Received 24.6.97; revised 29.1.98; accepted 19.3.98

Edited by C.J. Thiele

\begin{abstract}
Bile salts induce apoptosis and are implicated as promoters of colon cancer. The mechanisms by which bile salts produce these effects are poorly understood. We report that the cytotoxic bile salt, sodium deoxycholate (NaDOC), activates the key stress response proteins, NF- $\kappa$ B and poly(ADP-ribose) polymerase (PARP). The activation of NF- $k \mathrm{~B}$ and PARP, respectively, indicates that bile salts induce oxidative stress and DNA damage. The pre-treatment of cells with specific inhibitors of these proteins [pyrrolidine dithiocarbamate (NF$\kappa \mathbf{B}$ inhibitor) and 3-aminobenzamide (PARP inhibitor)] sensitizes cells to the induction of apoptosis by NaDOC, indicating that these stress response pathways are protective in nature. Colon cancer risk has been reported to be associated with resistance to apoptosis. We found an increase in activated NF- $\kappa$ B at the base of human colon crypts that exhibit apoptosis resistance. This provides a link between an increased stress response and colon cancer risk. The implications of these findings with respect to apoptosis and to colon carcinogenesis are discussed.
\end{abstract}

Keywords: NF- $\kappa$ B; PARP; apoptosis; bile acids; sodium deoxycholate; oxidative stress; DNA damage

Abbreviations: PARP, poly(ADP-ribose) polymerase; PAR, poly(ADP-ribose) polymers; $\mathrm{NaDOC}$, sodium deoxycholate; MNNG, $N$-methyl- $N$ '-nitro- $N$-nitrosoguanidine; PDTC, pyrrolidine dithiocarbamate; PBS, phosphate-buffered saline

\section{Introduction}

Epidemiologic and animal studies indicate that the development of colon cancer is related to diet (Ling, 1995), and is, therefore, potentially preventable. A typical Western style diet has been associated with a high incidence of colon cancer. Such a diet is high in fat and low in fiber, resulting in high levels of bile acids in the colon (Stadler et al, 1988). Conjugated bile acids released from the liver are deconjugated and converted to more cytotoxic secondary bile acids by bacterial flora present in the colon (Ling, 1995). Animal models of colon carcinogenesis have implicated these secondary bile acids as promoters of colon cancer (Reddy et al, 1977). The mechanism of tumor promotion by bile acids is, however, largely unknown.

The reported cellular effects of bile salts are varied, and include activation of protein kinase $\mathrm{C}$, membrane-derived phospholipases and specific transcription factors. In addition, bile salts cause an increase in cytoplasmic calcium levels and surface blebbing, the latter implying cytoskeletal perturbations. Some of these effects suggest that bile salts activate signal-transduction pathways leading to altered gene expression. From animal studies involving the intrarectal instillation of bile salts at very high, nonphysiologic levels $(5-25 \mathrm{mM})$ that resulted in extensive cellular lysis (Lapre et al, 1992), it was proposed that bile salts may contribute to colon cancer by causing cell death and compensatory cellular hyperproliferation (Lapre et al, 1992). Cellular lysis is presumably the result of a drastic alteration in membrane structure caused by the detergent action of the bile salts and/or their micellar cholesterolsolubilizing capacities (Lapre et al, 1992). We have shown however, that sodium deoxycholate ( $\mathrm{NaDOC})$, the bile salt present in highest concentration in the human colon and feces (Allinger et al, 1989), induces apoptosis in human colonic epithelial cells (Payne et al, 1995a) at concentrations accompanying a high-fat diet (Stadler et al, 1988). We also found that cells within the normal appearing mucosa of patients with a history of colon cancer are relatively resistant to bile acid-induced apoptosis (Payne et al, 1995a; Garewal et al, 1996). On the basis of these findings, we proposed a novel hypothesis concerning the promoting role of bile salts in the development of colon cancer (Payne et al, 1995a). On this hypothesis, the excessive apoptosis induced by bile salts, produced in response to a high fat diet, leads to the selection of apoptosis-resistant cells. If cells are apoptosisresistant, they may not die when they experience unrepaired DNA damage. This could lead, upon replication of the damaged DNA template, to mutation, cellular transformation and neoplasia. The development of apoptosis-resistant cell populations should place an individual at higher risk for cancer. 
In order to understand how resistance to bile saltinduced apoptosis can arise, it is important to determine how cells can compensate for bile salt-induced damages. We now report that bile salts induce two major stress response pathways, one mediated by $\mathrm{NF}-\kappa \mathrm{B}$, a redoxsensitive transcription factor (Schreck et al, 1991), and one mediated by poly(ADP-ribose) polymerase (PARP), an enzyme that is inactive unless single- or double-strand DNA breaks are present (Berger, 1985). PARP binds to DNA at the location of a break and covalently attaches polymers of ADP-ribose to proteins, including PARP itself. The auto-modification of PARP significantly increases negative charge in the area of the damage and allows DNA repair to take place (Shall, 1984). The induction of stress-response pathways indicates that bile salts, at the high physiologic concentrations that accompany a high fat diet, are damaging to cells. Thus, bile salts may cause oxidative stress and DNA damage, two stresses that may trigger apoptosis. We also found that inhibition of the NF$\kappa \mathrm{B}-$ and PARP-mediated stress responses results in enhanced bile salt-induced apoptosis. In addition, we found that the base of human colon crypts in colon segments excised from colon cancer patients exhibit an increase in the number of cells containing activated NF- $\kappa \mathrm{B}$. These same segments also display apoptosis resistance using a bile salt-induced apoptosis bioassay. This provides a link between constitutively increased stress responses and cancer risk.

\section{Results}

A sensitive semi-quantitative in situ imaging procedure was used to correlate cellular morphology with NF- $\kappa$ B and PARP activation induced by the cytotoxic bile salt, NaDOC. In situ imaging allowed separation of upstream stress events prior to the appearance of apoptotic cells from downstream stress events resulting from the execution of the cell itself. Such a distinction is not easily made with conventional biochemical assays. A further advantage of this approach is that there is no artifactual activation of $\mathrm{NF}-\kappa \mathrm{B}$ and PARP caused by experimental manipulation that is inherent in cell extraction procedures used in biochemical assays. Upstream stresses, if not sufficiently defended against, presumably lead to the death of the cell (Payne et al, 1995b). Confocal microscopy was used to measure the activation of NF- $\kappa$ B and PARP by employing antibodies against the activated $p 65$ subunit of NF$\kappa \mathrm{B}$ and the product of PARP activity, poly(ADP-ribose) polymers (PAR) that are 10-50 ADP-ribose units long. Two different cultured cell types, Jurkat and HCT-116, that are very sensitive to the induction of apoptosis by $\mathrm{NaDOC}$, as well as excised rat colon were used. HCT-116 and rat colonic epithelial cells were chosen in order to measure responses of colon-derived cells to bile salts.

PAR production was first measured using confocal images of Jurkat cells. The relative amount of PAR was first measured in cells treated for $30 \mathrm{~min}$ with $0.4 \mathrm{mM} \mathrm{N}$ methyl- $N$ '-nitro- $N$-nitrosoguanidine (MNNG), an alkylating agent that serves as a positive control for PARP activity in this assay (Kupper et al, 1996) (Figure 1A). Nucleotides that are modified by MNNG are removed through the base excision repair pathway resulting in strand breakage and activation of PARP. Figure 1B shows the increased levels of PAR in Jurkat cells after a $30 \mathrm{~min}$ exposure to $0.5 \mathrm{mM}$ NaDOC. This concentration of bile salts is in the high physiologic range that accompanies a high fat/low fiber diet (Stadler et al, 1988). Figure 1C shows the low uninduced levels of PAR in untreated control cells. However, there is a distinct punctate staining pattern predominantly in the nuclei of these untreated cells, probably indicating responses to endogenous DNA damages. Figure 1D shows the markedly reduced fluorescence intensity in the absence of the primary antibody. NaDOC-treated cells had $3.1 \times$ the fluorescence intensity of the uninduced cells exposed to the anti-PAR antibody, while MNNG-treated cells had $4.7 \times$ the intensity of uninduced cells and $1.5 \times$ the intensity of the NADOC-treated cells (Table 1). The differences between the mean values of these three treatment groups were each statistically significant $(P<0.001)$. Less than $20 \%$ of the NaDOC-treated cells, evaluated after their brief $30 \mathrm{~min}$ of treatment, were observed to be undergoing apoptosis, while all of the cells showed PARP activation.

In addition to nuclear staining, an unexpected finding was the presence of abundant PAR staining in the cytoplasm (Figure 1). Therefore, we assessed relative bile salt-induced poly(ADP-ribosylation) reactions in the nucleus and the cytoplasm, using confocal microscopy and digital image analysis. Untreated control cells exhibited a $1.6 \times$ higher level of PAR in the nucleus compared to the cytoplasm (Table 2). NaDOC-treated cells showed a $1.9 \times$ increase in the fluorescence intensity in the nucleus, and a $3.9 \times$ increase in the fluorescence intensity in the cytoplasm, compared to values in the control cells $(P<0.001)$ (Table 2).

Next, the Jurkat cells were tested to assess the role of a PARP inhibitor on bile salt-induced apoptosis. The induction of apoptosis by bile salts in suspensions of growing Jurkat cells is growth phase-dependent (unpublished observations). Thus, cells were treated under standardized logarithmic growth phase conditions. Apoptotic cells were identified using morphologic criteria (Payne et al, 1992, 1995b), the 'gold standard' for assessing this specific mode of cell death (Kerr et al, 1972). Cells were grown for $24 \mathrm{~h}$ in the presence or absence of $1 \mathrm{mM} 3-$ aminobenzamide (3-AB), an inhibitor of PARP activity, and then $\mathrm{NaDOC}$ was added to the growth medium $(0.5 \mathrm{mM}$ final concentration). Control cells received no bile salt. The $1 \mathrm{mM}$ concentration of $3-\mathrm{AB}$ used did not induce apoptosis by itself over the $24 \mathrm{~h}$ pretreatment period. It was

Table 1 Comparison of gray level intensity values of poly(ADP)-ribose) units induced by bile salts and an alkylating agent

\begin{tabular}{lcc}
\hline Treatment & Mean gray level values \pm S.E.M. \\
\hline Control & $19.43 \pm 1.37$ & $(277)^{1}$ \\
Sodiumdeoxycholate & $60.10 \pm 1.99$ & $(259)$ \\
MNNG & $92.15 \pm 3.02$ & $(323)$ \\
\hline
\end{tabular}

${ }^{1}$ Number of measurements made over a cluster of approx. 20 cells using a template of a regular array of dots in conjuction with SigmaScan software 

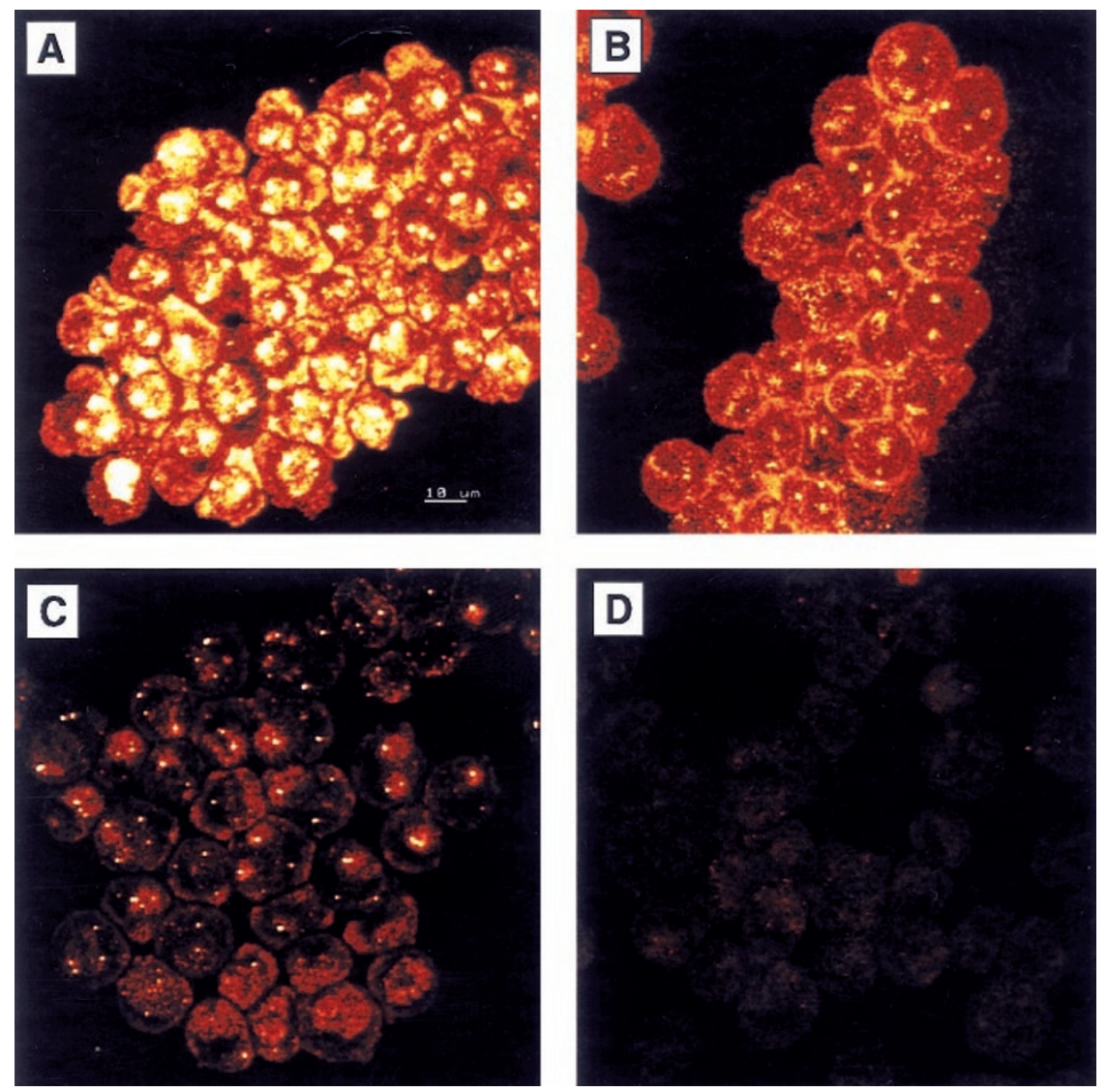

Figure 1 Confocal images of Jurkat cells reacted with a polyclonal antibody against PAR (A) Cells treated with $0.4 \mathrm{mM}$ MNNG for $30 \mathrm{~min}$; (B) Cells treated with $0.5 \mathrm{mM} \mathrm{NaDOC}$ for $30 \mathrm{~min}$; (C) Untreated control cells; (D) Control for the immunostaining reaction where the same staining procedure was followed as for (A), (B) and (C) above, except that the primary antibody was omitted

Table 2 Comparison of gray level intensity values of poly(ADP-ribose) units between nucleus and cytoplasm of control and bile salt-treated cells

\begin{tabular}{lcc}
\hline & \multicolumn{2}{c}{ Mean gray level values \pm S.E.M. } \\
Treatment & Nucleus & Cytoplasm \\
\hline Control & $27.53 \pm 5.49(51)^{1}$ & $16.97 \pm 1.70(29)$ \\
Sodium deoxycholate & $53.33 \pm 3.03(103)$ & $65.70 \pm 3.64(53)$ \\
\hline
\end{tabular}

${ }^{1}$ Number of measurements made over a cluster of approx. 20 cells using a template of a regular array of dots in conjunction with SigmaScan software

determined that the presence of $1 \mathrm{mM} 3-\mathrm{AB}$ under our conditions enhanced apoptosis in response to $\mathrm{NaDOC}$ (Figure 2). Treatment with NaDOC alone caused apoptosis to increase from $17 \%$ at 30 min of treatment to $59 \%$ at $4 \mathrm{~h}$ of treatment. The presence of $1 \mathrm{mM} 3-\mathrm{AB}$ caused apoptosis to increase from $22 \%$ at $30 \mathrm{~min}$ of $\mathrm{NaDOC}$ treatment to $98 \%$ at $4 \mathrm{~h}$ of treatment in the experiment shown in Figure 2. Similar results were obtained in two further experiments. Control experiments were then carried out to ensure that $3-A B$ pre-treatment actually decreases PARP activity in the above experiments. Jurkat cells were pre-treated with $1 \mathrm{mM} 3-\mathrm{AB}$ for $24 \mathrm{~h}$ and then challenged for $30 \mathrm{~min}$ with $0.4 \mathrm{mM}$ MNNG. Control cells were reacted with $0.4 \mathrm{mM}$ MNNG for $30 \mathrm{~min}$ in the absence of any pretreatment with $3-\mathrm{AB}$. Cells were spun onto coverslips, fixed with $100 \%$ methanol, and the amount of PAR produced as a result of PARP activity was evaluated using confocal microscopy and digital image analysis. There was a $23-$ $26 \%$ reduction in the amount of PAR produced as a result of PARP inhibition using 3-AB pre-treatment (Table 3). The $26 \%$ reduction in PARP activity was calculated from the data obtained using a point counting method of gray level measurements (SigmaScan; see top of Table 3). The $23 \%$ reduction in PARP activity was calculated from the data obtained using an automated intensity histogram method of measurement (Image-Pro Plus software; see bottom of Table 3). The differences between mean fluorescent intensity values were statistically significant $(P<0.001$, SigmaScan analysis; $P<0.001$, Image-Pro-Plus analysis). Apparently, a $23-26 \%$ reduction in PARP activity caused by $3-A B$ pre-treatment is sufficient to sensitize cells to NaDOC-induced apoptosis (Figure 2). The fluorescence intensity levels of the MNNG-treated cells shown in Table 1 cannot be compared to the fluorescent intensity of the MNNG-treated cells in Table 3, since in the latter case the cells were at a lower density and, therefore, less susceptible to stress and apoptosis (unpublished results). The data in Table 3 were obtained under the same growth 

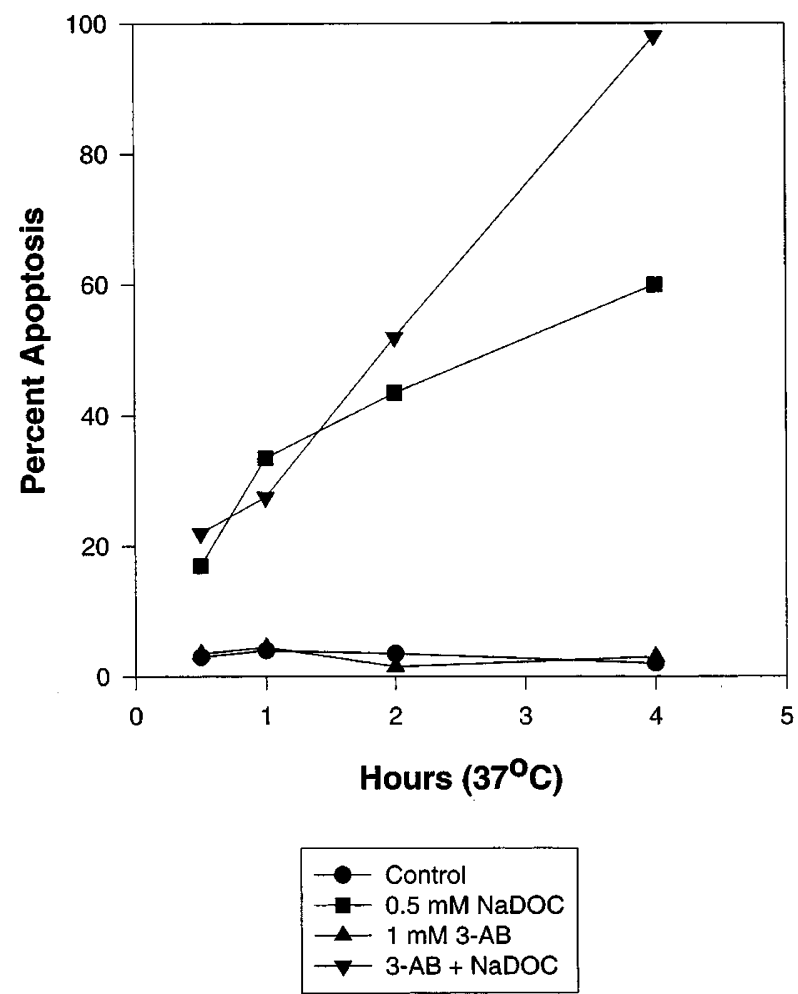

Figure 2 Representative experiment showing the effect of the presence of $1 \mathrm{mM} 3-\mathrm{AB}$ on NaDOC-induced apoptosis of Jurkat cells. Cells were allowed to enter logarithmic growth and then grown for $24 \mathrm{~h}$ in the presence or absence of $1 \mathrm{mM}$ 3-AB until time zero. At time zero, NaDOC was added to cells either at $0.0 \mathrm{mM}$ or $0.5 \mathrm{mM}$ final concentration. Per cent apoptosis is plotted against hours of incubation at $37^{\circ} \mathrm{C}$ after time zero. Per cent apoptosis was determined using morphologic criteria as described in Materials and Methods. (Similar results were obtained in two additional experiments)

Table 3 Comparison of gray level intensity values of poly(ADP-ribose) units of MNNG-treated Jurkat cells in the presence and absence of 3-aminobenzamide

\begin{tabular}{|c|c|c|}
\hline \multirow{2}{*}{$\begin{array}{l}\text { Treatment } \\
\text { MNNG-treated } \\
\text { MNNG+3-AB }\end{array}$} & \multicolumn{2}{|c|}{ Mean gray level values \pm S.E.M. } \\
\hline & $\begin{array}{l}37.55 \pm 1.57 \\
27.63 \pm 1.32\end{array}$ & $\begin{array}{l}(275)^{2} \\
(272)\end{array}$ \\
\hline 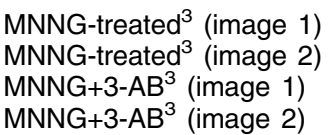 & $\begin{array}{l}18.25 \pm 0.05 \\
18.17 \pm 0.04 \\
14.37 \pm 0.03 \\
13.85 \pm 0.03\end{array}$ & $\begin{array}{l}(109939)^{4} \\
(179885) \\
(168596) \\
(193456)\end{array}$ \\
\hline
\end{tabular}

${ }^{1}$ Two separate fields of approximately 20 cells/field were analyzed by SigmaScan software. The points from both of the images were combined for making the comparison between mean values.

${ }^{2}$ Number of measurements made using a template of a regular array of dots. ${ }^{3}$ Individual images analyzed by tracing the group of cells in each image and obtaining an automated intensity mean and standard deviation using Image-Pro Plus (Media Cybernetics software program).

${ }^{4}$ Total number of pixels analyzed in each image

conditions that were necessary to show that $3-A B$ pretreatment sensitized cells to apoptosis (Table 2).

PARP activation was next measured in excised rat colon tissue. Here, normal rat colon tissue treated in vitro for $2 \mathrm{~h}$ with $0.4 \mathrm{mM}$ MNNG showed strong PARP activation
(Figure 3A). There was intense staining throughout the crypt. PARP activation also occurred in rat colon treated in vitro for $2 \mathrm{~h}$ with $1.0 \mathrm{mM} \mathrm{NaDOC}$ (Figure $3 \mathrm{~b}$ ). The amount of PAR present in the crypts after MNNG treatment (Figure $3 A$ ) was greater than after NaDOC treatment (Figure $3 b$ ), and greater after NaDOC treatment than in the untreated control (Figure $3 \mathrm{C}$ ). This was evidenced by the brighter reddish-brown staining (using the 'glow' lookup table of the Leica confocal microscope) in the MNNG-treated tissue compared with the NaDOC-treated tissue, and in the NaDOC-treated tissue compared with the control. The bright white spots within the epithelial layers in all tissue samples (Figures $3 A, B, C$ ) indicate the strongest areas of PARP activation (oversaturation of the grey scale). PARP activation was observed at all levels of the crypt after MNNG or NaDOC treatment, with extremely high activity in cells in the lower third of the crypt. These findings are consistent with biochemical assays that reported the highest PARP activity in the lower third of normal, unstressed crypts of the small intestine (Kerridge, 1979; Porteous et al, 1979) using a selective epithelial stripping technique (Porteous et al, 1979).

An evaluation of the extent of apoptosis in the crypts at the same time as the assessment of PARP activation indicated the absence of apoptotic cells within the crypts. Apoptotic cells were, however, identified in their usual location at the surface epithelium and in the lumen of the colon. In control tissue, incubated without MNNG or NaDOC, Par was expressed mostly at the surface epithelium (Figure 3C). Individual cells showing intense PAR formation (white spots) can be seen near the luminal surface of these untreated cells. When the primary antibody was omitted, no staining could be seen (Figure 3D). The results obtained after excised colonic tissue was treated with NaDOC (Figure 3B) are similar to those obtained after treatment of cultured Jurkat cells with NaDOC (Figure 1B) in that PARP activation and, by inference, DNA strand breaks, occurred as upstream events prior to the appearance of apoptotic cells.

High physiologic levels of NaDOC $(0.5-1.0 \mathrm{mM})$ induced activation and nuclear translocation of $\mathrm{NF}-\kappa \mathrm{B}$ in HCT-116 cells (Figure 4), colonic epithelial cells that are very sensitive to NaDOC-induced apoptosis (unpublished observations). Figure 4 is a composite of confocal images of untreated (Figure 4A) and bile salt-treated HCT-116 cells (Figure $4 \mathrm{~b}$ ) showing the localization of NF- $\kappa \mathrm{B}$ (green color) and $\mathrm{I}_{\kappa} \mathrm{B}-\gamma$ (red color), a member of the $\mathrm{I} \kappa \mathrm{B}$ family of $\mathrm{NF}-\kappa \mathrm{B}$ inhibitory proteins, in the same cells. The distribution of $\mathrm{I}_{\kappa} \mathrm{B}-\gamma$ is identified using a polyclonal antibody, and activated $\mathrm{NF}-\kappa \mathrm{B}$ is identified using a monoclonal antibody against an epitope of the p65 subunit of NF- $\kappa$ B which is normally masked in the unactivated cell by the $I_{\kappa} \mathrm{B}$ family of proteins. $I \kappa \mathrm{B}-\gamma$ is visualized using a Texas red immunofluorescent tag, and $\mathrm{NF}-\kappa \mathrm{B}$ is visualized in the same section using a fluorescein tag (see Materials and Methods for details). Areas of the cell that contain only activated NF- $\kappa \mathrm{B}$ appear green, areas that contain only $\mathrm{I} \kappa \mathrm{B}-\gamma$ appear red, and areas where they co-localize appear orange to yellow. In the untreated cells (Figure 4A) the cytoplasm appears predominantly orange to red, indicating an abundance of 

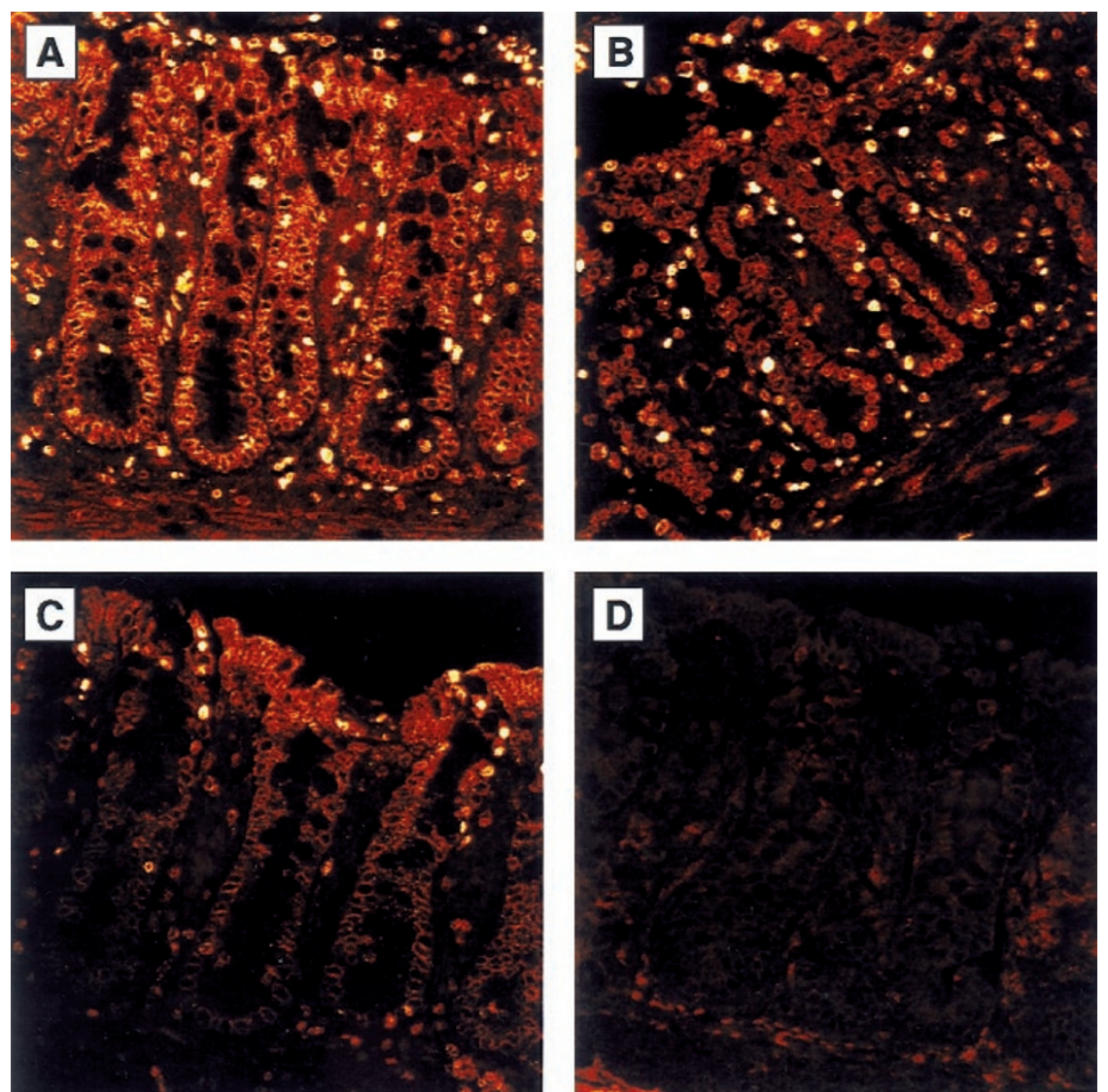

Figure 3 Five micron sections of paraffin-embedded rat colon stained with a polyclonal antibody against PAR. (A) Tissue was incubated with $0.4 \mathrm{mM}$ MNNG for $2 \mathrm{~h}$; (B) Tissue was incubated with $1.0 \mathrm{mM} \mathrm{NaDOC}$ for $2 \mathrm{~h}$; (C) Control tissue that was allowed to incubate for $2 \mathrm{~h}$ in the absence of MNNG- and NaDOC; (D) Control for the immunostaining reactions where the same staining procedure was followed as for (A), (B) and (C) above, except that the primary antibody was omitted
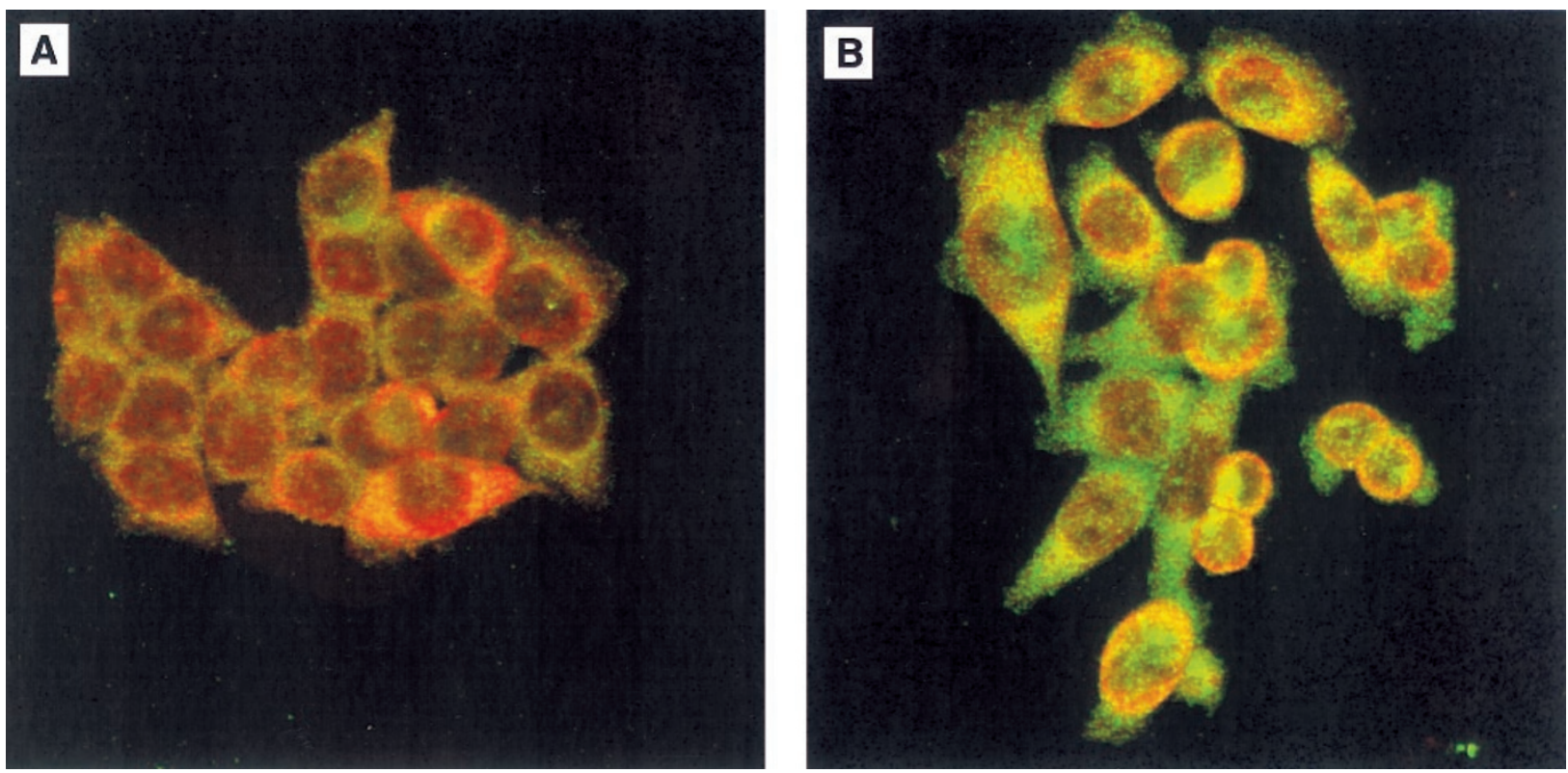

Figure 4 Confocal images of NF- $\kappa$ B and $I_{\kappa} \mathrm{B}-\gamma$ localization in the nucleus and cytoplasm of HCT-116 colon cells. Cells were reacted with polyclonal antibody against $I_{\kappa} \mathrm{B}-\gamma$ (red) followed by monoclonal antibody against the activated $\mathrm{p} 65$ subunit of NF- $\kappa$ B (green), using an immunofluorescent biotin/avidin sandwich technique. Areas of co-localization appear orange to yellow. (A) Untreated control cells; (B) Cells treated with $0.5 \mathrm{mM} \mathrm{NaDOC}$ for $4 \mathrm{~h}$ at $37^{\circ} \mathrm{C}$ 


\section{NF-kB Response Element-Fusion Construct (HepG2)}

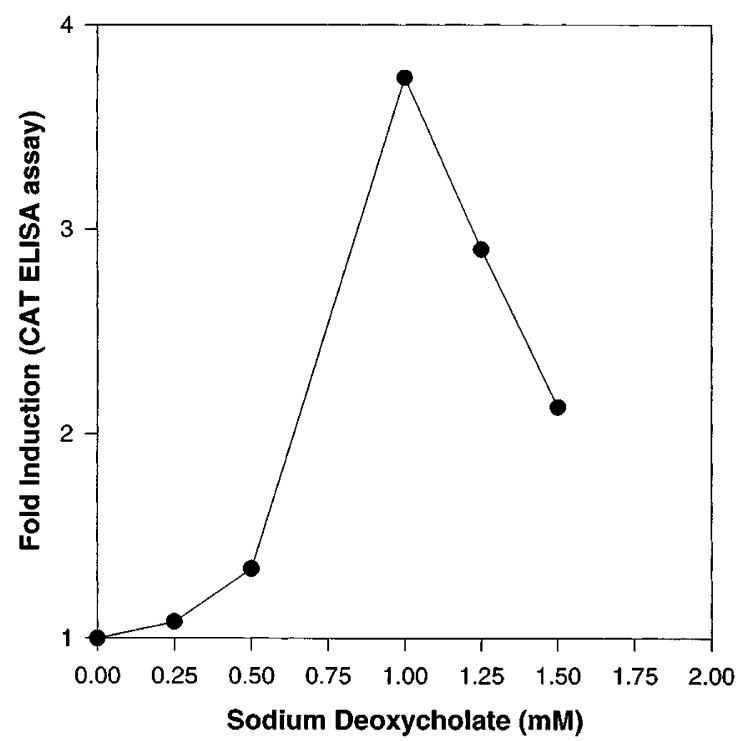

Figure 5 Dose-response curve (concentration of sodium deoxycholate vs fold induction of CAT activity) using an NF $k$ BRE-fusion construct stably integrated into HepG2 cells. CAT activity was assessed using an ELISA assay

$\mid \kappa \mathrm{B}-\gamma$. Although there is a small amount of green fluorescence in the cytoplasm of these unstimulated cells, the nuclei are virtually devoid of any color, indicating the absence of both NF- $\kappa \mathrm{B}$ and $\mathrm{I}_{\kappa} \mathrm{B}-\gamma$ in that cellular compartment. Figure $4 \mathrm{~B}$ is a representative image of HCT-116 cells treated with $0.5 \mathrm{mM} \mathrm{NaDOC}$ for $4 \mathrm{~h}$. The presence of an intense green fluorescence in the nuclei indicates that the activated form of NF- $\kappa$ B has translocated to that compartment. The activated form of NF- $\kappa \mathrm{B}$ is also identified in the cytoplasm, as evidenced by the intense green fluorescence in the cytoplasm of some cells and the orange and yellow color in other cells where it co-localizes with $\mathrm{I}_{\kappa} \mathrm{B}-\gamma$.

The activation of NF- $\kappa \mathrm{B}$ by $\mathrm{NaDOC}$ that was observed using immunofluorescence and confocal microscopy was confirmed using $\mathrm{NaDOC}$ activation of an NF- $\kappa \mathrm{B}$ response element (NF $\kappa \mathrm{BRE}$ )-fusion construct stably integrated into a HepG2 cell line (Todd et al, 1995). A dose-response curve [concentration of NaDOC vs fold induction in chloramphenicol acetyl transferase (CAT) protein] is shown in Figure 5. The greatest induction of CAT protein occurred at $1.0 \mathrm{mM}$ $\mathrm{NaDOC}$, the concentration that most effectively induced apoptosis in normal human colonic epithelial cells in vitro (Garewal et al, 1996).

To determine if NF- $\kappa \mathrm{B}$ activation is a reaction on the pathway to apoptosis or is protective in nature, Jurkat cells were grown for $2 \mathrm{~h}$ before time zero in the presence or absence of $1.0 \mu \mathrm{M}$ or $10 \mu \mathrm{M}$ pyrrolidine dithiocarbamate (PDTC), a potent inhibitor of NF- $\kappa$ B. At zero time, NaDOC was added to the growth media $(0.5 \mathrm{mM}$ final concentration). Control cells received no bile salt. In the absence of
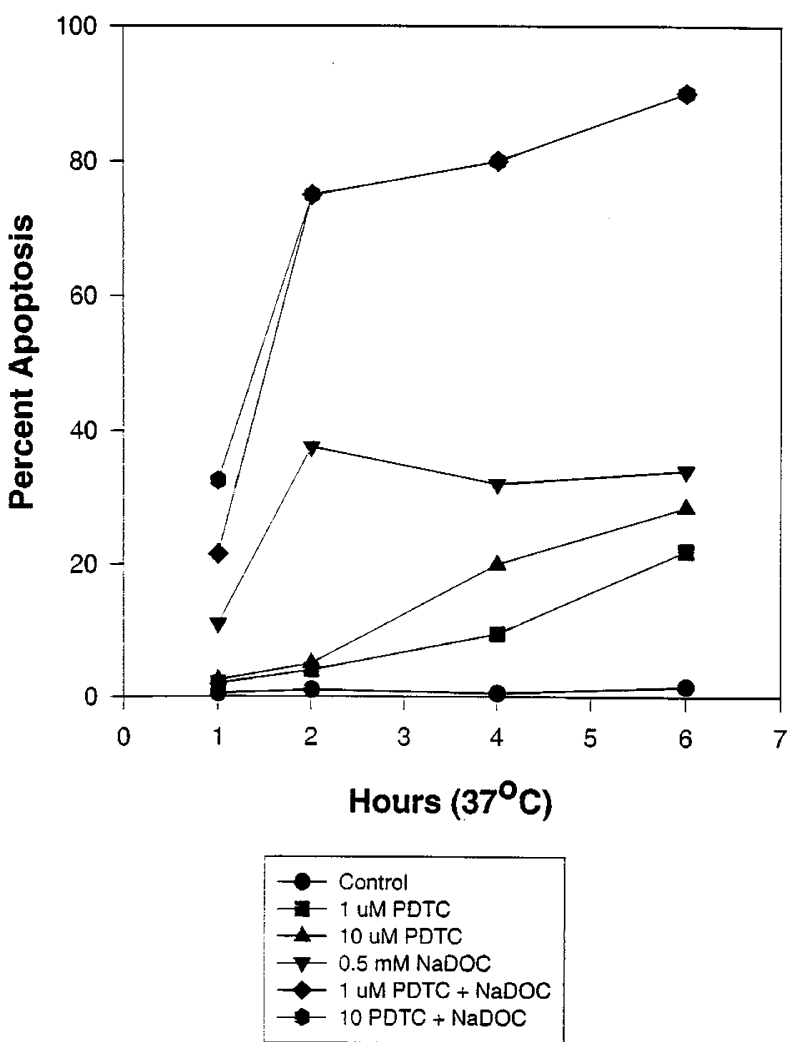

Figure 6 Effect of micromolar concentrations of PDTC on NaDOC-induced apoptosis. Cells were grown in the presence or absence of PDTC for $2 \mathrm{~h}$ before time zero. At time zero, $\mathrm{NaDOC}$ was added to the growth medium $(0.5 \mathrm{mM}$ final concentration). Control cells received no bile salts. Per cent apoptosis was determined using morphologic criteria, at the indicated times of incubation after time zero. (Similar results were obtained in two additional experiments)

PDTC, $34 \%$ of the cells were apoptotic after $6 \mathrm{~h}$ of treatment with $0.5 \mathrm{mM} \mathrm{NaDOC}$. However, in the presence of PDTC at either $1.0 \mu \mathrm{M}$ or $10.0 \mu \mathrm{M}, 90 \%$ of the cells were apoptotic after $6 \mathrm{~h}$ treatment with $0.5 \mathrm{mM} \mathrm{NaDOC}$ (Figure $6)$. Growth in the presence of $1.0 \mu \mathrm{M}$ or $10 \mu \mathrm{M}$ PDTC, alone, caused $20-28 \%$ apoptosis at $6 \mathrm{~h}$ after time zero. Therefore, we tested whether a concentration of PDTC that did not induce any apoptosis could also sensitize the cells to NaDOC-induced apoptosis. Cells exposed to $100 \mathrm{nM}$ PDTC for $2 \mathrm{~h}$ before time zero and for $6 \mathrm{~h}$ of growth after time zero showed no induction of apoptosis (Figure 7). This concentration of PDTC in the growth media sensitized the cells to the apoptosis-inducing effects of NaDOC. Treatment of cells for $6 \mathrm{~h}$ with $0.5 \mathrm{mM} \mathrm{NaDOC}$ in the absence of PDTC caused $54 \%$ of cells to undergo apoptosis (Figure 7); growth of cells in the presence of $100 \mathrm{nM}$ PDTC and $6 \mathrm{~h}$ incubation with $0.5 \mathrm{mM} \mathrm{NaDOC}$ caused $87 \%$ of cells to undergo apoptosis. Control experiments were then carried out to ensure that PDTC functioned to inhibit NF- $\kappa$ B. The levels of activated NF- $\kappa$ B in untreated control Jurkat and HCT-116 cells were compared to cells pretreated with $10 \mu \mathrm{M}$ PDTC for $2 \mathrm{~h}$ (Table 4). The differences in mean $\mathrm{NF}-\kappa \mathrm{B}$ levels between control and PDTC-treated cells were 

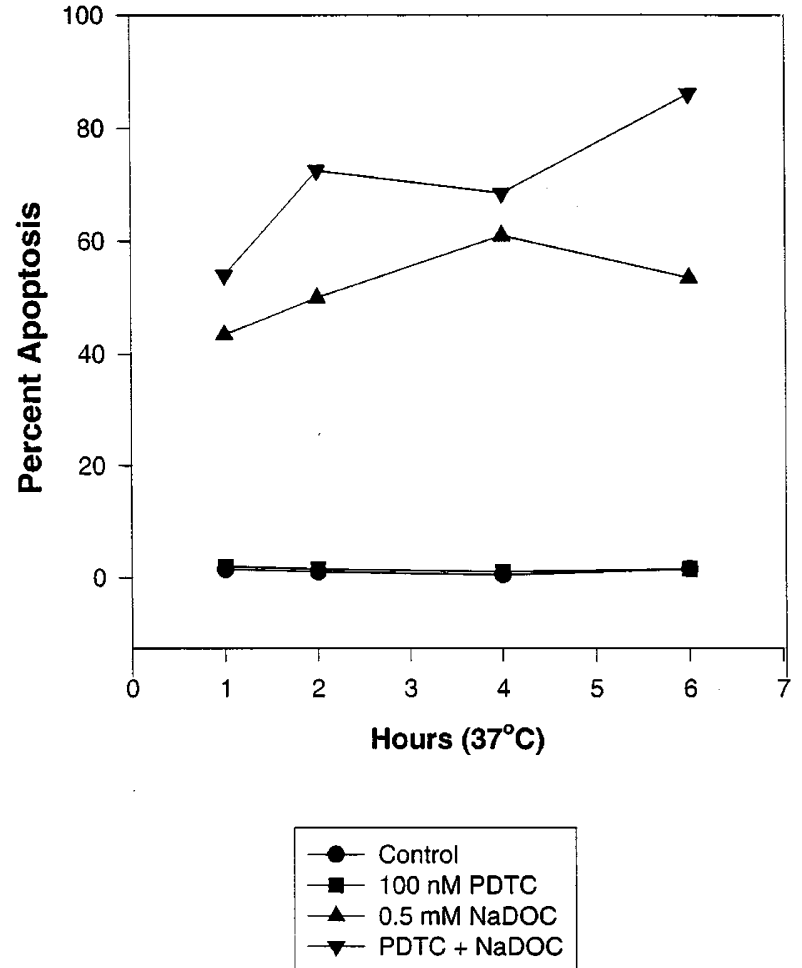

Figure 7 Effect of 100 nanomolar PDTC on NaDOC-induced apoptosis. Cells were grown in the presence or absence of $100 \mathrm{nM}$ PDTC for $2 \mathrm{~h}$ before time zero. At time zero, NaDOC was added to the growth medum (final concentration of $0.5 \mathrm{mM} \mathrm{NaDOC}$ ). Control cells received no bile salts. Per cent apoptosis was determined using morphologic criteria, at the indicated times of incubation after time zero. (Similar results were obtained in two additional experiments)

Table 4 Comparison of activated NF- $k$ B (gray level intensity values) in the presence and absence of PDTC

\begin{tabular}{lr}
\hline Treatment & Mean gray level values \pm S.E.M. \\
\hline Control Jurkat & $198.28 \pm 3.00(114)^{1}$ \\
PDTC-treated Jurkat & $79.44 \pm 2.54(86)$ \\
Control HCT-116 & $120.89 \pm 4.71(88)$ \\
PDTC-treated HCT-116 & $42.27 \pm 1.80(132)$ \\
\hline
\end{tabular}

${ }^{1}$ Number of measurements made over a cluster of approximately 20 cells using a template of a regular array of dots in conjuction with SigmaScan software

statistically significant $(P<0.001)$. PDTC treatment reduced constitutive activated NF- $\kappa$ B levels in Jurkat cells by $60 \%$ and in HCT-116 cells by $65 \%$.

We next addressed the question of whether colon epithelial cells which are resistant to apoptosis have a high level of activated $\mathrm{NF}-\kappa \mathrm{B}$, as would be expected if activated NK- $\kappa \mathrm{B}$ were protective. These experiments were carried out from biopsy specimens of the 'normal' mucosa taken from a length of colon that had been resected from a patient with an adenocarcinoma of the colon. It was determined that biopsies taken at two different locations in the normal appearing portion of the colon differed significantly in resistance to NaDOC-induced apoptosis.
After treatment with $1.0 \mathrm{mM} \mathrm{NaDOC}$ for $3 \mathrm{~h}$ at $37^{\circ} \mathrm{C}$ in a humidified $\mathrm{CO}_{2}$ incubator, the percentage of apoptotic goblet cells was $16 \%$ in the resistant region and $57 \%$ in the sensitive region. An adjacent biopsy specimen from these two distinct regions, fixed in ethanol and embedded in paraffin, was stained for activated NF- $\kappa$ B using an immunohistochemical procedure. The number of cells (goblet and non-goblet) with activated NF- $\kappa \mathrm{B}$ was then counted in the sensitive and resistant regions of the colon resection and the difference in mean values statistically evaluated. We found that the apoptosis resistant region had a significantly higher level of activated NF- $\kappa \mathrm{B}$ compared to the sensitive region in the basal portion of the crypt, but not in the luminal portion (Figure 8 ). The NF- $\kappa \mathrm{B}$ labeling index was $2.2 \times$ higher in the basal cells in the apoptosisresistant region of the colon compared with the apoptosissensitive region. This indicates that a patch of the 'normal' appearing mucosa of a patient with colon cancer exhibited a higher level of constitutively activated NF- $\kappa \mathrm{B}$, and that this patch also had resistance to bile salt-induced apoptosis. An increase in activated NF- $\kappa \mathrm{B}$ may be part of the underlying mechanism of resistance that places patients at risk for colon cancer (see Discussion).

\section{Discussion}

We have shown that the secondary bile salt, $\mathrm{NaDOC}$, at concentrations that accompany a Western-type diet, induces two major stress pathways in cells. This induction was evidenced by the activation of PARP and NF- $\kappa$ B. Activation of PARP is known to occur in response to DNA damage (Berger, 1985). The finding of PARP activation after NaDOC treatment of Jurkat cells and colonic epithelial cells in excised rat colon is consistent with previous observations from our lab (Watabe and Bernstein, 1985; Kandell and Bernstein, 1991; Zheng and Bernstein, 1992) and those reported in the literature (Kulkarni et al, 1980), indicating that bile salts cause DNA damage. It can be further concluded, from the in situ imaging used here, that bile salt activation of PARP is an upstream event in relation to apoptosis, since all Jurkat cells showed an increase in the level of PAR at $30 \mathrm{~min}$ of treatment, a time when less than $20 \%$ of these cells showed evidence of apoptosis. In rat colon tissue, PARP was activated at all levels of the crypts while apoptosis was only seen at the surface epithelium, where it is usually present even without treatment. The finding that PARP is activated by bile salts before entry into apoptosis suggests that PARP activation is part of the cellular response to bile salt-induced damage. There was, however, a greater amount of PARP activation in the lower third of the crypts after MNNG and NaDOC treatment. This could be explained by an increase in oxidative stress and DNA damage induced in the more proliferative compartment of the crypt. These findings are also consistent with biochemical assays that report the highest PARP activity in the lower third of normal, unstressed crypts (Kerridge, 1979; Porteous et al, 1979). It is probable that the lower third of the normal crypt is under more oxidative stress than the upper two thirds because of its increased proliferative capacity. The increase in bcl-2 expression in the lower half of the crypt, including the stem cell region, in both mouse and human 

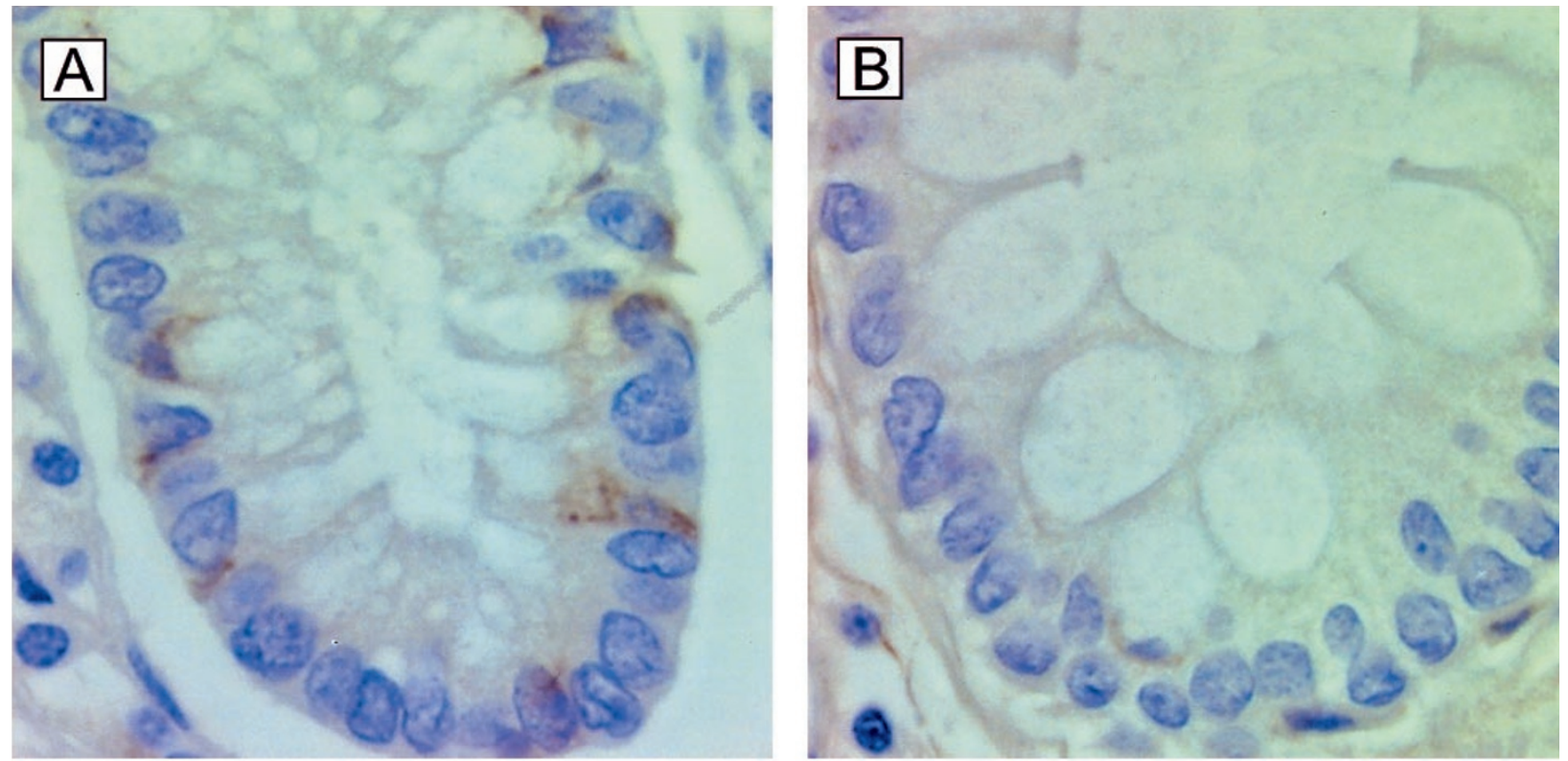

C

\section{NFאB Labeling Indices in Basal and Luminal Regions of Colonic Crypts}

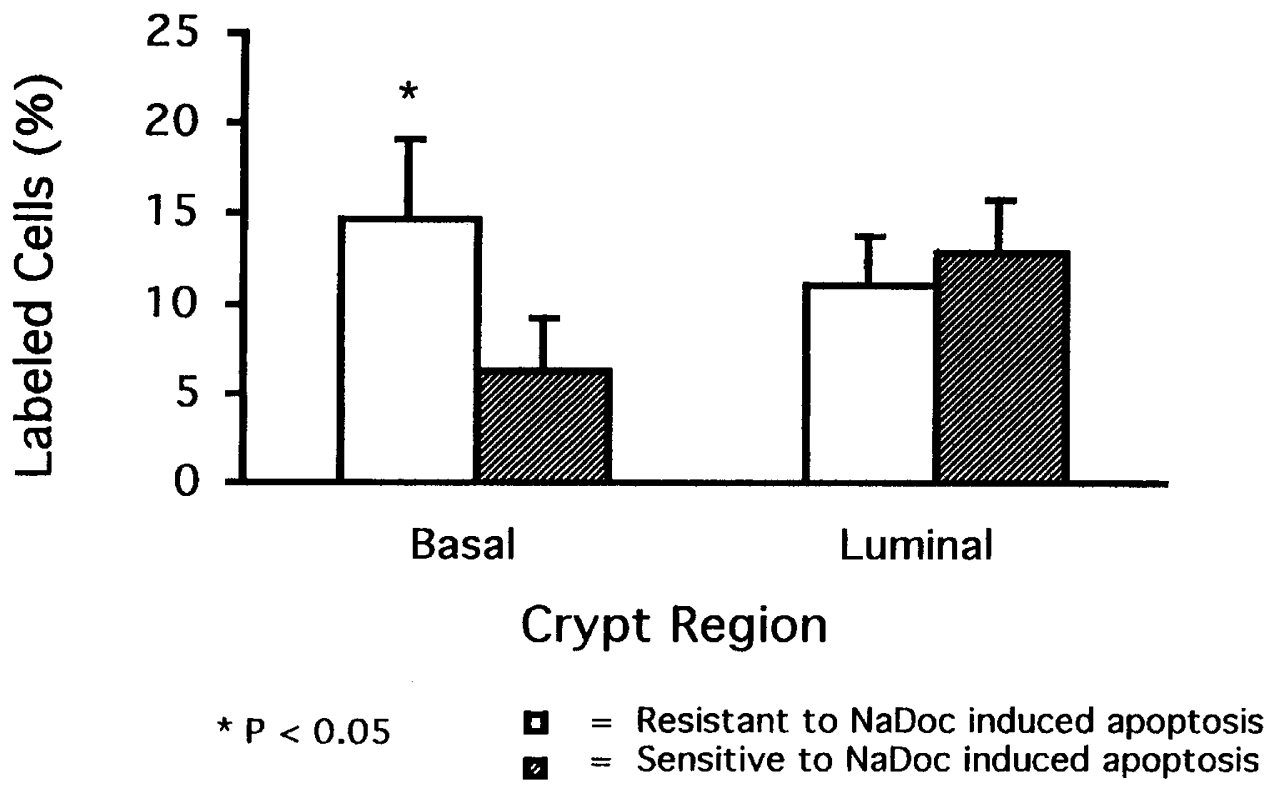

Figure 8 Immunohistochemical staining $(\mathbf{A}, \mathbf{B})$ and quantitation $(\mathbf{C})$ of activated NF- $\kappa$ B in the normal mucosa of a patient with colon cancer obtained during a surgical resection of a portion of the colon. Five micron paraffin sections were prepared from two distinct areas of the mucosa (distance from the tumor), one showing resistance to NaDOC-induced apoptosis and the other showing sensitivity to NaDOC-induced apoptosis. (A) Paraffin section from an area of the mucosa showing apoptosis resistance. The section was stained with a monoclonal antibody against the activated form of NF- $\kappa \mathrm{B}$, and then reacted with a biotinylated goat anti-mouse lgG, followed by reaction with Avidin: Biotinylated Enzyme Complex (ABC). Note the distinct brown staining of the diaminobenzidine tetrahydrochloride (DAB) reaction product in the nucleus and cytoplasm of cells at the base of the crypt. (B) Paraffin section from an area of the mucosa showing apoptosis sensitivity. Note the lack of brown staining at the base of the crypt, which was representative of most of the crypt regions in the sample. (C) Comparison of the number of epithelial cells reactive with the antibody against activated NF- $\kappa$ B in the apoptosis-resistant and apoptosis-sensitive areas of the mucosa. Note that there was a significantly greater mean percentage of labeled cells in the basal area (cell positions $1-30$ ) of the apoptosis-resistant region compared to the basal area of the apoptosis-sensitive region 
colonic mucosa, could be a protective mechanism against endogenous oxidant stress-induced apoptosis. These endogenous oxidative stresses are probably the result of increased aerobic metabolism in this proliferative compartment. Increased PARP activity found at this location (Kerridge, 1979; Porteous et al, 1979) may, therefore, be a protective response allowing DNA damage to be repaired.

While poly(ADP-ribosylation) reactions occur predominantly in the nucleus, we found a greater evidence of PARP enzyme activity in the cytoplasm compared with the nucleus after NaDOC treatment of Jurkat cells. Although it has been suggested from cell cycle studies that cytoplasmic PARP exists and may be transported to the nucleus at the time of DNA synthesis (Roberts et al, 1975), there was no evidence that PARP functions to produce polymers of ADP-ribose in a cytoplasmic location. Perhaps the excess of cytoplasmic ADP-ribose polymers identified with the PAR antibody in the present study represents large glycohydrolase cleavage products that are transported to the cytoplasm for further degradation.

The activation of PARP appears to be protective of cellular survival, since inhibition of PARP with a classic inhibitor, 3-AB, sensitized cells to NaDOC-induced apoptosis. Thus, in this experimental system, PARP activation appears to protect against apoptosis, presumably through the enhancement of DNA repair (Shall, 1984). Our results are consistent with the reported finding that PARP is a substrate for several of the caspases during the execution phase of the apoptotic process (Kaufmann et al, 1993). Kaufmann et al (1993) have demonstrated that the cleavage of PARP during apoptosis removes the aminoterminal domain to yield a protein fragment that retains basal catalytic activity but lacks the DNA-binding domain. The PARP cleavage product has a much lower catalytic activity than the intact polymerase since binding to nicked DNA is needed to stimulate PARP activity (Kaufmann et al, 1993). In addition, PARP normally ADP-ribosylates the $\mathrm{Ca}^{++} / \mathrm{Mg}^{++}$-activated endonuclease (Yoshihara et al, 1975), and inhibits its activity (Yoshihara et al, 1975). The cleavage of PARP during apoptosis, therefore, would allow the endonuclease to damage DNA, resulting in the characteristic ladder of DNA fragmentation in some cells. Once a cell is committed to cell death, it would be logical for it to eliminate the major defense proteins that assist in DNA repair and overall cell survival (Casciola-Rosen et al, 1996).

An increase in PARP activity has been reported in adenomatous polyps and cancers of the colon (Hirai et al, 1983). It is possible that up-regulation of DNA repair enzymes could contribute to the apoptosis resistance we found in normal appearing colon tissue in patients with a history of colon cancer (Payne et al, 1995a; Garewal et al, 1996). However, it is unclear whether an increase in PARP activity in neoplastic tissue is in response to a high level of endogenous DNA damage (e.g. due to increased oxidative stress) or due to constitutive upregulation of PARP itself.

Although bile salts have been reported to induce the formation of oxygen free radicals (Craven et al, 1986), activation of $\mathrm{NF}-\kappa \mathrm{B}$, a redox-sensitive transcription factor (Schreck et al, 1991) has not previously been demonstrated in bile salt-treated cells. In fact, Hirano et al (1996) were unable to detect NF- $\kappa \mathrm{B}$ activation in nuclear extracts of sodium chenodeoxycholate-treated LoVo adenocarcinoma cells using electrophoretic mobility shift assays (EMSA). These investigators also could not detect an increase in expression of an NF- $\kappa$ B-luciferase reporter construct after bile salt treatment. It is unclear if the discrepany between our results and those of Hirano et al (1996) is due to the use of different bile salts, different concentrations of bile salts, different cell lines or the specific techniques used (EMSA or immunofluorescence/confocal microscopy). NF$\kappa \mathrm{B}$ proteins normally exist in abundance in the cytoplasm of most cells (Beg and Baltimore, 1996; Grilli et al, 1993). Since NF- $\kappa$ B can be activated in the presence of RNA and protein synthesis inhibitors, preformed molecules of $N F-\kappa B$ are believed to be activated in response to environmental stresses. After stimulation by a variety of agents, including agents that induce oxidative stress [e.g. tumor necrosis factor (TNF) $-\alpha$ (Beg and Baltimore, 1996)], NF- $\kappa$ B enters an activated state (concomitant with $\mathrm{I}-\kappa \mathrm{B}$ degradation or phosphorylation) in which the nuclear localization signal sequence is exposed. This allows the activated NF- $\kappa \mathrm{B}$ to cross the nuclear pores, resulting in translocation to the nuclear compartment. Once within the nucleus, activated $\mathrm{NF}-\kappa \mathrm{B}$ binds to NF- $\kappa \mathrm{B}$ binding sites on DNA and activates a large number of genes (Grilli et al, 1993). Portions of this sequence of events could be ascertained using immunofluorescent staining in conjuction with confocal microscopy. The activation of $\mathrm{NF}-\kappa \mathrm{B}$ in the cytoplasm and its translocation to the nucleus were easily demonstrated using an antibody that is directed against an epitope of the p65 subunit of the NF- $\kappa \mathrm{B}$ dimer that is normally masked by $\mathrm{l} \kappa \mathrm{B}$ (Kaltschmidt et al, 1995). We also demonstrated that $\mathrm{NaDOC}$ activates NF- $\kappa \mathrm{B}$ using an NF $\kappa \mathrm{BRE}$-fusion construct and measuring the accumulation of CAT protein in stably transfected cells. In situ molecular imaging, however, was an important technique to use in the present study, since the activation and translocation of NF- $\kappa \mathrm{B}$ to the nucleus could be observed in pre-apoptotic cells. This places the NF- $\kappa \mathrm{B}$ signaling event upstream of the agonal event characterized by the morphologic appearance of apoptosis.

Since NF- $\kappa \mathrm{B}$ activation ordinarily occurs in response to oxidative stress and $\mathrm{NaDOC}$ activates $\mathrm{NF}-\kappa \mathrm{B}$, it is probable that $\mathrm{NaDOC}$ induces oxidative stress in these cells. Apoptosis induced by TNF- $\alpha$, another oxidative stressinducing agent, is potentiated by the inhibition of $\mathrm{NF}-\kappa \mathrm{B}$ (Beg and Baltimore, 1996). Furthermore, evidence was presented that $\mathrm{NF}-\kappa \mathrm{B}$ is involved in the regulation (or prevention) of apoptosis (Baeuerle and Baltimore, 1996). Inhibition of NF- $\kappa \mathrm{B}$ activity by lactacystin (a proteasome inhibitor), microinjection with $\mid \kappa \mathrm{B}$ - $\alpha$-glutathione-S-transferase fusion protein (a purified specific inhibitor), or microinjection with an antibody against p65 protein, were all shown to promote apoptosis in a nontransformed murine hepatocyte cell line (Bellas et al, 1997). Mayo et al (1997) also reported that NF- $\kappa$ B activation was a requirement for the suppression of p53-independent apoptosis induced by oncogenic ras. We similarly found that apoptosis induced by $\mathrm{NaDOC}$ is potentiated by inhibition of $\mathrm{NF}-\kappa \mathrm{B}$. The 
increases in apoptosis after TNF- $\alpha$ or NaDOC treatment in the presence of PDTC are inconsistent with the idea that $\mathrm{NF}-\kappa \mathrm{B}$ is on the pathway to apoptosis, as was previously suggested in other experimental systems (Bessho et al, 1994), and suggest that NF- $\kappa \mathrm{B}$ activation protects against stresses leading to apoptosis. Constitutive oxidant defense levels in human colonic epithelial cells are relatively low compared with liver cells (Grisham et al, 1990). Thus, bile salt activation of $\mathrm{NF}-\kappa \mathrm{B}$ in vivo may be needed to protect colonic epithelial cells from oxidative stresses caused by bile salts that would otherwise lead to apoptosis.

Since bile salts activate a DNA damage-responsive pathway (PARP) and an oxidative stress-responsive pathway $(\mathrm{NF}-\kappa \mathrm{B})$, bile salts may induce apoptosis through DNA damage, oxidative stress, or both. The body tissues that are normally exposed to occasional high levels of bile salts as a result of diet may need apoptosis as a final defense mechanism after the defense capabilities of the protective pathways are exceeded. A long term high fat/low fiber diet, however, may cause so much apoptosis that apoptosisresistant cells are selected for. We have shown that resistance to bile salt-induced apoptosis is associated with a higher risk for colon cancer (Garewal et al, 1996). Of particular clinical relevance in the present study was the finding of an increase in the number of cells with activated $\mathrm{NF}-\kappa \mathrm{B}$ in the 'normal' appearing mucosa of a patient with colon cancer. We also demonstrated that this region of the colon exhibited resistance to NaDOC-induced apoptosis, using our standard apoptosis bioassay (Payne et al, 1995a; Garewal et al, 1996). The results from the present study indicate that cells with a 'survival phenotype', that is cells excessively protected against environmental stresses (Israel, 1996), may be associated with an elevated risk for colon cancer. Excessive protection against apoptosis for an extended period of time may allow cells with unrepaired DNA damage to propagate, a situation that could lead to cellular transformation, neoplasia and frank malignancy. The increased activation of $\mathrm{NF}-\kappa \mathrm{B}$, in particular, has been shown to lead to cellular transformation (Kitajima et al, 1992), tumorigenicity (Higgins et al, 1993; Sharma and Narayanan, 1996) and a metastatic phenotype (Bours et al, 1994). These findings indicate that future therapeutic agents, directed at interfering with the function of key transcription factors, may prove to be an effective treatment for cancer.

One mechanism of apoptosis resistance could involve an unbalanced up-regulation of one or more antioxidant defense or DNA repair enzyme, possibly through increased transcription mediated by activated NF- $\kappa \mathrm{B}$. We have identified two distinct NF- $\kappa$ B oligonucleotide binding sites in the human PARP promoter (Table 5). One of these NF$\kappa \mathrm{B}$ binding sequences fits the classic decameric consensus $\kappa \mathrm{B}$ binding sequence. The other NF- $\kappa \mathrm{B}$-like binding sequence identified in the PARP promoter is $90 \%$ homologous to the CK-1-like binding site, which is reported to bind the p65 (Rel A) subunit of NF- $\kappa \mathrm{B}$ but not the p50 (NFKB1) subunit (Sharma and Narayanan, 1996). It is possible that activation of NF- $\kappa \mathrm{B}$ could serve to protect cells against bile salt-induced apoptosis by upregulating PARP gene expression, which, ultimately, could protect cells against excessive DNA damage and apoptosis. Other genes with $\mathrm{NF}-\kappa \mathrm{B}$ binding sites in their non-coding regions may be involved in protection against apoptosis. For example, the $3^{\prime}$ end of the non-coding region of the MnSOD gene contains an NF- $\kappa \mathrm{B}$ binding site (Wan et al, 1994). Although MnSOD mRNA levels have been reported to decline during glucocorticoid-induced apoptosis (Briehl et al, 1995), the regulation of MnSOD in response to stresses induced by bile salts has not been explored.

Figure 9 is a model, based on the findings described herein in conjunction with published results, which indicates the fate of cells after interaction with high physiologic concentrations of bile salts. According to this model, bile salts cause oxidative stress and/or DNA damage in cells resulting in induction of the stress response proteins PARP and $\mathrm{NF}-\kappa \mathrm{B}$, and perhaps others. Cells that have adequate levels of activated NF- $\kappa \mathrm{B}$, antioxidant and/or DNA repair enzymes are more likely to repair the damage caused by bile salts and, therefore, to survive as normal cells. Cells that have an inadequate stress response are more likely to undergo apoptosis. It is also possible that cells with genetic or epigenetic changes causing high constitutive levels of stress-response proteins could produce clones of apoptosis-resistant cells. Such cells may fail to undergo apoptosis in the presence of DNA damage, and thus be able to replicate their DNA in the presence of damage, giving rise to further mutations, some of which could lead to cancer. We suggest that there is normally a balance between stress responses which protect the cell and inhibit the triggering of apoptosis and an altruistic apoptosis response to delete the body of cells that have unrepaired DNA and other damages.

We have shown that bile salts activate two major stress pathways and that these pathways protect cells from bile salt-induced apoptosis. The levels of bile salts which induce these pathways are those found in fecal water after ingestion of a Western high fat/low fiber diet. These findings increase our understanding of the links between diet, bile acids, cellular stress, apoptosis and the possible development of apoptosis-resistant clones in the cascade of events during colon carcinogenesis.

\section{Materials and Methods}

\section{Chemicals}

Pyrrolidine dithiocarbamate was obtained from Sigma (St. Louis, MO), 3-aminobenzamide from Aldrich (Milwaukee, WI) and sodium deoxycholate from ICN Biochemicals (Cleveland, Ohio).

Table $5 \mathrm{NF}-\kappa \mathrm{B}$ binding sites in the poly(ADP-ribose) polymerase promoter

\begin{tabular}{lll}
\hline & $\begin{array}{c}\kappa \text { B binding } \\
\text { sequence }\end{array}$ & $\begin{array}{c}\text { CK-1 binding } \\
\text { sequence }\end{array}$ \\
\hline Consensus & GGGRNNYYCC $^{1}$ & GAGATTCCAC \\
PARP promoter & GGGAAACTCC $^{2}$ & GAGATTCCCC $^{2}$ \\
\hline
\end{tabular}

${ }^{1}$ Position -79 to $-885^{\prime}$ upstream of the transcription initiation site (Ogura et al., 1990). ${ }^{2}$ Position -945 to $-9545^{\prime}$ upstream of the transcription initiation site (Ogura et al, 1990) 


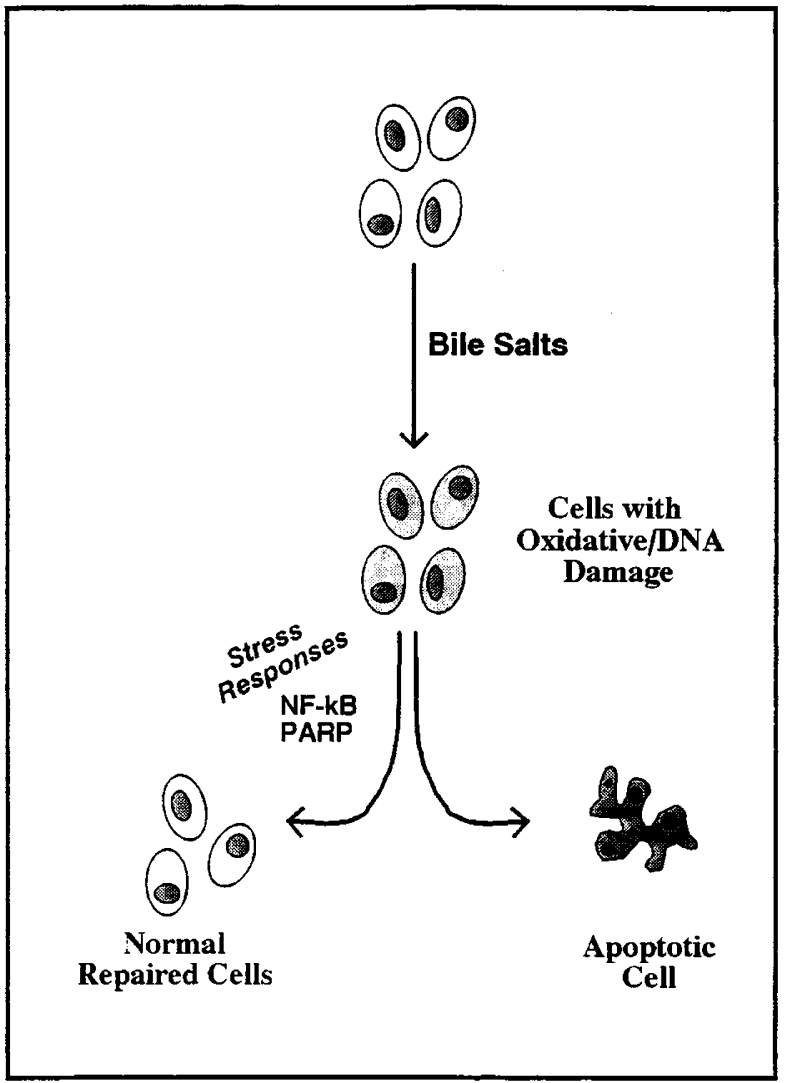

Figure 9 Model indicating the fate of cells after interaction with high physiologic concentration of bile salts. A cell that has missing or inadequate stress response proteins may undergo apoptosis. Cells with adequate stress response proteins likely repair any damage and survive as normal cells. Surviving cells with genetic or epigenetic changes causing high constitutive levels of stress-response proteins in vivo, could produce clones of resistant cells that become prone to further mutations, some of which lead to cellular transformation and neoplasia

\section{Cell cultures}

The Jurkat cell line was derived from a human T-cell lymphoma [American Type Culture Collection (ATCC), Bethesda, MD; ATCC \#TIB 152]. Jurkat cells were cultured in RPMI 1640 media (Irvine Scientific, Santa Ana, CA) and supplemented with $10 \%$ fetal calf serum (FCS) (Omega Scientific, Inc, Tarzana, CA), $100 \mathrm{U} / \mathrm{ml}$ penicillin, $100 \mu \mathrm{g} / \mathrm{ml}$ streptomycin and $3.44 \mathrm{mg} / \mathrm{ml}$ L-glutamine (Gibco BRL Life Technologies, Grand Island, NY). The HCT-116 cell line (ATCC \#CCL 247) was derived from a patient with colon cancer. HCT-116 cells were cultured in DMEM media and supplemented with $10 \%$ FCS, penicillin/ streptomycin/glutamine (same concentrations as for Jurkat cells) and $1 \%$ MEM non-essential amino acids (Sigma, St Louis, MO). HepG2 is a transformed human hepatoma cell line (ATCC \#HB 8065). HepG2 cells were grown in MEM medium containing $10 \%$ FCS, $50 \mu \mathrm{g} / \mathrm{ml}$ streptomycin, $50 \mathrm{U} / \mathrm{ml}$ penicillin, $100 \mu \mathrm{M}$ MEM non-essential amino acids, $2 \mathrm{mM} \mathrm{L-glutamine} \mathrm{and} 1 \mathrm{mM}$ sodium pyrruvate (Gibco).

\section{Preparation of cultured cells for confocal microscopy}

$N F-\kappa B(p 65) / / \kappa B-\gamma$ co-localization HCT-116 cells were grown on $0.17 \mathrm{~mm}$ thick coverslips in a $\mathrm{CO}_{2}$-humidified incubator at $37^{\circ} \mathrm{C}$ and fixed after various treatments with $4 \%$ methanol-free formaldehyde for
$20 \mathrm{~min}$ at room temperature. Jurkat cells, which are suspension cells, were spun onto coverslips using a Shandon Cytospin 3 cytocentrifuge. We have empirically determined that the antigenicity and cytoplasmic localization of the p65 and $\mid \kappa \mathrm{B}-\gamma$ antigens in unstimulated cells were best preserved using methanol-free formaldehyde (Ted Pella, Inc. Redding, CA) rather than alcohol. To make the $4 \%$ formaldehyde, a $10 \mathrm{ml}$ ampule of $16 \%$ formaldehyde in water was mixed with $10 \mathrm{mls}$ of $2 \times$ PBS. This was then diluted to $4 \%$ formaldehyde by adding $20 \mathrm{ml}$ $1 \times$ PBS, as a working solution for fixing cells. This can be stored in the refrigerator for 1 month.

Poly(ADP-ribose)(PAR) polymers To determine the best method of fixation to detect the PAR polymers using the polyclonal guinea pig antibody (Trevigen, Inc., Gaithersberg, MD) in our cells and tissues, we fixed Jurkat cells in $4 \%$ formaldehyde (methanol-free) made up in PBS for $20 \mathrm{~min}$ at room temperature, or ice-cold $10 \%$ trichloracetic acid for 10 min (method of Kupper et al, 1996), or 100\% methanol for $5 \mathrm{~min}$ at room temperature. All coverslips were additionally permeabilized in $100 \%$ methanol at $-20^{\circ} \mathrm{C}$ for 6 min, air-dried and stored at freezer temperatures until time of immunostaining. For the excised rat colon, we fixed the tissue overnight at room temperature in $4 \%$ formaldehyde (methanol-free) made up in PBS or ice-cold $10 \%$ trichloracetic acid for $30 \mathrm{~min}$ (followed by transfer to $70 \%$ ethanol overnight at room temperature), or primary fixation in $70 \%$ ethanol overnight at room temperature. Of the three fixation methods used, the highest reactivity of the polyclonal anti-poly(ADP-ribose) antibody was observed after fixation with $100 \%$ methanol for 5 min for tissue culture cells and overnight fixation in $70 \%$ ethanol for the excised rat tissue.

Excised rat colon treatment Excised colon tissue was rinsed with PBS and incubated in modified essential medium (MEM) (Sigma, St. Louis, MO) supplemented with $2 \% \mathrm{v} / \mathrm{v}$ of a glutamine solution (Gibco $\mathrm{BRL}, \mathrm{Grand}$ Island, NY) and with $1 \% \mathrm{v} / \mathrm{v}$ of non-essential amino acids (Sigma, St. Louis, MO) for $2 \mathrm{~h}$ at $37^{\circ} \mathrm{C}$ in a humidified $\mathrm{CO}_{2}$ incubator in the presence or absence of $1.0 \mathrm{mM} \mathrm{NaDOC}$ or $0.4 \mathrm{mM}$ MNNG. A concentration of $1.0 \mathrm{mM} \mathrm{NaDOC}$ was chosen for the colon tissue, as we have determined that this concentration results in a significant amount of apoptosis over this short incubation period in vitro. Incubation periods longer than $2 \mathrm{~h}$ result in the sloughing of the colonic epithelium, making evaluation of tissue architecture difficult. For immunofluorescent studies, tissue was fixed overnight in $70 \%$ alcohol and embedded in paraffin.

\section{Antibodies and detection systems}

$N F-\kappa B / l \kappa B-\gamma \quad A$ monoclonal antibody against an epitope of the p65 subunit of NF- $\kappa$ B that is exposed during NF- $\kappa$ B activation was obtained from Boehringer Mannheim (Indianapolis, IN). This antibody was used a dilution of $1: 100$ using $1 \%$ bovine serum albumin as diluent. The detection system consisted of a biotinylated goat antimouse secondary antibody obtained from Vector Laboratories, Inc, Burlingame, CA, followed by fluorescein-conjugated streptavidin (Vector Laboratories).

A polyclonal antibody was made in a rabbit against a peptide corresponding to amino acids 471-490 within the carboxy terminal domain of human $\mathrm{I}_{\kappa \mathrm{B}}-\gamma \mathrm{p} 70$ by Santa Cruz Biotechnology, Inc., Santa Cruz, CA. This was used at a dilution of $1: 20$ followed by a biotinlylated goat anti-rabbit secondary antibody. Final visualization was achieved using Texas Red-conjugated streptavidin from Vector Laboratories, Inc. (Burlingame, CA). The fluorescent emission spectra of fluorescein, used to visualize NF- $\kappa \mathrm{B}$, and Texas Red, used to visualize $I_{\kappa} \mathrm{B}-\gamma$, are separable with no bleed-through, using the filter sets on a Leica TCS-4D laser scanning confocal microscope, which allowed for simultaneous scanning. 
Poly(ADP-ribose) polymers The evaluation of PARP activity can be asssessed using an antibody against the product of PARP enzyme activity, ADP-ribose polymers. The polyclonal antibody was produced in a guinea-pig (Trevigen, Inc., Gaithersburg, MD) and reacts with poly(ADP-ribose) polymers that are 10-50 ADP-ribose units long. This antibody was used at a dilution of $1: 500$, followed by a biotinylated goat anti-guinea-pig secondary antibody at a 1:100 dilution. The final visualization of ADP-ribose polymers was achieved using Cy 5conjugated streptavidin from Jackson ImmunoResearch Laboratories, Inc., West Grove, PA. Cy 5-conjugated streptavidin was used in conjunction with $25 \mathrm{nM}$ YOYO-1 iodide, obtained from Molecular Probes (Eugene, OR) to stain DNA after RNAase digestion. This allowed for the localization of ADP-ribose polymers in the nuclear and cytoplasmic compartments. All coverslips were mounted using a watersoluble mounting media that hardens overnight, from DAKO Corp., Carpenteria, CA. To ensure that this antibody actually recognized ADP-ribose polymers, control experiments were performed in which the PAR antibody was reacted with poly(ADP-ribosylated) protein $(0.5 \mathrm{mg} / \mathrm{ml})$ (Trevigen) for $90 \mathrm{~min}$ prior to immunostaining. MNNGtreated Jurkat cells that were immunostained with the reacted PAR antibody exhibited a significantly reduced level of immunostaining compared with the unreacted PAR antibody.

\section{Immunohistochemical staining and quantitation of activated NF- $\kappa$ B in human colon resections and correlation with apoptosis resistance}

Samples of colonic mucosa were obtained immediately after colon resection in the operating room. The surgeon (JW, a co-author on this paper) removed the mucosa from regions proximal and distal to the adenocarcinoma using a sharp scissors. The tissue was immediately placed into ice-cold MEM media, which was kept on ice. The excised mucosal samples were brought back to the laboratory, at which time samples were prepared for the apoptosis-resistance bioassay and others were placed immediately into $70 \%$ ethanol.

Resistance to apoptosis bioassay Mucosal samples were incubated in the presence or absence of $1.0 \mathrm{mM} \mathrm{NaDOC}$ in supplemented MEM media at $37^{\circ} \mathrm{C}$ in a humidified $\mathrm{CO}_{2}$ incubator for $3 \mathrm{~h}$, as previously described (Payne et al, 1995a; Garewal et al, 1996). After the incubation period, the media was removed and replaced with ice-cold, half-strength Karnovsky's fixative, and fixed overnight; the tissue was then dehydrated in a graded series of ethanols and embedded in Spurr's epoxy resin, as previously described. One micron sections were prepared and stained with a polychrome stain, which differentially stains the goblet cells (Garewal et al, 1996). At least 200 goblet cells were scored for the quantitation of apoptotic cells.

Immunohistochemistry and $N F-\kappa B$ quantitation The ethanol-fixed tissue was dehydrated in a graded series of alcohols and embedded in paraffin. Five micron sections were prepared and deparaffinized. Then endogenous peroxidase was blocked by incubating the slides with $0.3 \%$ hydrogen peroxide in methanol for $30 \mathrm{~min}$, and the sections rinsed with distilled water and PBS. Non-specific binding was blocked by incubating the sections in rabbit serum (Vector) at 1:10 dilution in PBS for $30 \mathrm{~min}$. The same monoclonal antibody against activated NF$\kappa \mathrm{B}$ that was used for the immunofluorescent/confocal microscopy studies above was used for this immunohistochemical procedure. The antibody was diluted 1:100 using 1\% BSA/PBS as diluent, and the tissue sections were incubated for $1 \mathrm{~h}$ at room temperature. The tissue was subsequently incubated with biotinylated rabbit anti-mouse IgG $(1: 1000)$ for $30 \mathrm{~min}$, then reacted for $30 \mathrm{~min}$ with the $A B C$ (Avidin:Biotinylated Enzyme Complex) kit (Vector Laboratories, Inc., CA). The sections were developed for $5 \mathrm{~min}$ in $0.5 \mathrm{mg} / \mathrm{ml}$ diaminobenzidine tetrahydrochloride (DAB) (Sigma Chemical Co., $\mathrm{MO}$ ) made up in PBS containing $0.015 \%$ hydrogen peroxide. Sections were counterstained with Mayer's hematoxylin (Sigma) and mounted using Crystal Mount.

\section{Semi-quantitative digital image analysis of confocal images}

All laser scans, when making comparisons of confocal images, were obtained by keeping the laser power and voltage on the photomultiplier tube (PMT) of a LEICA confocal microscope at a constant setting so that relative fluorescence intensity values could be compared. A line averaging value of 32 , to reduce electronic noise from the PMT, was applied to all images. Randomly obtained clusters of cells (approximately 20-25 cells to a cluster) were selected by means of nuclear fluorescence visualization (YOYO-1 staining, Molecular Probes) after RNAase digestion, using the xenon lamp attachment to the fluorescent microscope. Digital images were saved to a Zip diskette and imported into the hard drive of a PC containing SigmaScan image analysis software (Jandel Scientific, Corte Madera, CA). A template of a regular array of dots was placed over the image and multiple measurements were made, as previously described (Baker et al, 1997). Certain gray level intensity measurements were also made using the automatic histogram analysis of pixelated images (Image-Pro Plus software, Media Cybernetics, Silver Spring, MD). This latter method has the advantage of automatically acquiring a large number of intensity measurements, since all of the pixels in the circumscribed area of interest are evaluated, which usually number in the hundreds of thousands. This gives one a large $n$ value, markedly reducing the standard error, making comparisons between images with small differences in intensity values feasible.

Quantitation of NF- $k B$-stained crypt cells The visualization of the NF$\kappa \mathrm{B}$-stained colonic crypt cells (using the extent of brown staining of the $D A B$ reaction product) was facilitated by the projection of the stained slide through a SONY 3CCD RGB color video camera (interfaced with a Zeiss Axioskop microscope) onto a SONY Trinitron 20" color video monitor. The color video monitor receives signals from the video camera via an analog RGB input connector. The sections were viewed using a $100 \times$ oil immersion objective lens, and the cell position of the stained cells along the crypt axis was recorded using a FoxPro crypt analysis program developed at the Arizona Cancer Center.

\section{Identification and quantitation of apoptotic cells in tissue culture cells}

Cells were fixed with $100 \%$ methanol for 2 min at room temperature, air-dried and then stained at a later time with a 1:10 dilution of a $0.4 \%$ w/v modified Giemsa stain made in a buffered methanol solution, pH 6.9 (Sigma Diagnostics, St. Louis, MO). Two hundred cells were scored for apoptosis under a $100 \times$ oil immersion objective using a bright field microscopy as previously described (Payne et al, 1992). The criteria used to identify apoptotic cells in whole mount preparations were condensed chromatin, fragmented nuclei, cell shrinkage, cytoplasmic vacuolization and apoptotic body formation as previously described (Payne et al, 1992; Zheng et al, 1996).

\section{NF- $\kappa$ B response element (NF $\kappa$ BRE)-CAT ELISA assays}

The HepG2 cells were transfected with the pSP-CAT plasmid by electroporation using a gene pulser (Bio-Rad Laboratories, Richmond, 
CA), as previously described (Todd et al, 1995). The pSP-CAT plasmid contains four $\mathrm{NF}_{\kappa} \mathrm{BRE}$ consensus sites from the human immunodeficiency virus long terminal repeat fused to the CAT gene (a gift of $\mathrm{Dr}$ Gary J. Nabel, University of Michigan Medical Center, Ann Arbor, MI to Xenometrix, Boulder, CO; Shannon Beard, co-author on this manuscript). The pSP-CAT plasmid contains the bacterial chloramphenicol acetyl transferase gene and the SV40 early promoter, but lacks the SV40 enhancer. After treatment of HepG2 cells with varying concentrations of $\mathrm{NaDOC}$, the cells were lysed and the lysate transferred to 8-well microtiter strips coated with anti-CAT antibodies. The CAT ELISA was performed according to the protocol described in the Xenometrix CAT-Tox assay manual, and the microtiter plates were read at an absorbance of $405 \mathrm{~mm}$ in a microtiter plate reader (Bio-Tek Instruments, Inc). The data were collected and analyzed using Xenometrix software (Todd et al, 1995).

\section{Acknowledgements}

This work was supported in part by NIEHS grant \#ES06694 (Experimental Pathology Core support; Southwest Environmental Health Sciences Center small grant award), Arizona Disease Control Research Commission grant \#9621, NIH Institutional Core Grant \#CA23074, NIH PPG \#CA72008, Innovite, Inc. (Tigard, Oregon) and Biomedical Diagnostics \& Research, Inc (Tucson, Arizona).

\section{References}

Allinger UG, Johansson GK, Gustafsson J-A and Rafter JJ (1989) Shift from a mixed to a lactovegetarian diet: influence on acidic lipids in fecal water-a potential risk factor for colon cancer. Amer. J. Clin. Nutr. 50: 992-996

Baeuerle PA and Baltimore D (1996) NF- $\kappa$ B: Ten years later Cell 87: 13-20

Baker A, Payne CM, Briehl MM and Powis G (1997) Thioredoxin, a gene found overexpressed in human cancer, inhibits apoptosis in vitro and in vivo. Cancer Res. 57: 5162-5167

Beg AA and Baltimore D (1996) An essential role for NF- $\kappa$ B in preventing TNF- $\alpha-$ induced cell death. Science 274: 782-784

Bellas RE, FitzGerald MJ, Fausto N and Sonenshein GE (1997) Inhibition of NF- $\kappa$ B activity induces apoptosis in murine hepatocytes. Amer. J. Pathol. 151:891-896

Berger NA (1985) Symposium: Cellular response to DNA damage: The role of poly(ADP-ribose). Poly(ADP-ribose) in the cellular response to DNA damage. Rad. Res. 101: 4-15

Bessho R, Matsubara K, Kubota M, Kuwakado K, Hirota H, Wakazono Y, Lin YW, Okuda A, Kawai M, Nishikomori R and Heike, T (1994) Pyrrolidine dithiocarbamate, a potent inhibitor of nuclear factor $\kappa \mathrm{B}(\mathrm{NF}-\kappa \mathrm{B})$ activation, prevents apoptosis in human promyelocytic leukemia $\mathrm{HL}-60$ cells and thymocytes. Biochem. Pharmacol. 48: 1883-1889

Bours V, Dejardin E, Goujon-Letawe F, Merville M-P and Castronovo V (1994) The NF- $\kappa$ B transcription factor and cancer: high expression of NF- $k$ B and $l_{\kappa} B-$ related proteins in tumor cell lines. Biochem. Pharmacol. 47: 145-149

Briehl MM, Cotgreave IA and Powis G (1995) Downregulation of the antioxidant defence during glucocorticoid-mediated apoptosis. Cell Death Different. 2: 4146

Casciola-Rosen L, Nicholson DW, Chong T, Rowan KR, Thornberry NA, Miller DK and Rosen A (1996) Apopain/CPP32 cleaves proteins that are essential for cellular repair: A fundamental principle of apoptotic death. J. Exp. Med. 183: 1957-1964

Craven PA, Pfanstiel J and DeRubertis FR (1986) Role of reactive oxygen in bile salt stimulation of colonic epithelial proliferation. J. Clin. Invest. 77: 850-859

Garewal H, Bernstein H, Bernstein C, Sampliner Rand Payne C (1996) Reduced bile acid-induced apoptosis in 'normal' colorectal mucosa: A potential biological marker for cancer risk. Cancer Res. 56: 1480-1483

Grilli M, Chiu JJ-S and Lenardo MJ (1993) NF- $\kappa$ B and rel. Participants in a multiform trancriptional regulatory system. Int. Rev. Cytol. 143: 1-62

Grisham MB, MacDermott RP and Deitch EA (1990) Oxidant defense mechanisms in the human colon. Inflammation 14: 669-680
Higgins KA, Perez JR, Coleman TA, Dorshkind K, McComas WA, Sarmiento UM, Rosen CA and Narayanan R (1993) Antisense inhibition of the p65 subunit of NF$\kappa B$ blocks tumorigenicity and causes tumor regression. Proc. Natl. Acad. Sci. USA 90: 9901-9905

Hirai K, Ueda K and Hayaishi O (1983) Aberration of poly(adenosine diphosphateribose) metabolism in human colon adenomatous polyps and cancers. Cancer Res. 43: 3441-3446

Hirano F, Tanaka H, Makino Y, Okamoto K, Hiramoto M, Handa Hand Makino I (1996) Induction of the transcription factor AP-1 in cultured human colon adenocarcinoma cells following exposure to bile acids. Carcinogenesis 17: $427-433$

Israel L (1996) Tumour progression: Random mutations or an integrated survival response to cellular stress conserved from unicellular organisms? J. Theor. Biol. 178: $375-380$

Kaltschmidt C, Kaltschmidt B, Henkel T, Stockinger H and Baeuerle PA (1995) Selective recognition of the activated form of transcription factor NF- $\kappa$ B by a monoclonal antibody. Biol. Chem. Hoppe-Seyler 376: 9-16

Kandell RL and Bernstein C (1991) Bile salt/acid induction of DNA damage in bacterial and mammalian cells: Implications for colon cancer. Nutrition and Cancer 16: 227-238

Kaufmann SH, Desnoyers S, Ottaviano Y, Davidson NE and Poirier GG (1993) Specific proteolytic cleavage of poly(ADP-ribose) polymerase: An early marker of chemotherapy-induced apoptosis. Cancer Res. 53: 3976-3985

Kerr JFR, Wyllie AH and Currie AR (1972) Apoptosis: a basic biological phenomenon with wide-ranging implications in tissue kinetics. Br. J. Cancer 26: 239-257

Kerridge DF (1979) Estimation of the ratio (gamma) of poly(ADP-ribose) synthetase activity in non-lower-crypt cells to that in lower-cryptcells in vivo from an analysis of enzyme activities and thymidine incorporation in populations of sequentially isolated cells. Biochem. J. 180 (Appendix): 462-463

Kitajima I, Shinohara T, Bilakovics J, Brown DA, Xu X and Nerenberg M (1992) Ablation of transplanted HTLV-1 Tax-transformed tumors in mice by antisense inhibition of NF- $\kappa$ B. Science 258: 1792-1795

Kulkarni MS, Heidepriem PM and Yielding KL (1980) Production of lithocholic acid of DNA strand breaks in L1210 cells. Cancer Res. 40: 2666-2669

Kupper J-H, Van Gool L, Muller M and Burkle A (1996) Detection of poly(ADP-ribose) polymerase and its reaction product poly(ADP-ribose) by immunocytochemistry. Histochem. J. 28: 391-395

Lapre JA, TermontDSML, Groen AK and Van der MeerR(1992) Lytic effects of mixed micelles of fatty acids and bile acids. Am J Physiol 263: G333-337

Ling WH (1995) Diet and colonic microflora interaction in colorectal cancer. Nutrit. Res. 15: 439-454

Mayo MW, Wang C-Y, Cogswell PC, Rogers-Graham KS, Lowe SW, Der CJ and Balwin Jr AS (1997) Requirement of NF- $k$ B activation to suppress p53independent apoptosis induced by oncogenic ras. Science 278: 1812-1815

Ogura T, Nyunoya H, Takahashi-Masutani M, Miwa M, Sugimura T and Esumi H (1990) Characterization of a putative promoter region of the human poly(ADPribose) polymerase gene: structural similarity to that of the DNA polymerase beta gene. Biochem. Biophys. Res. Comm. 167: 701-710

Payne CM, Bernstein H, Bernstein C and Garewal H (1995a) Role of apoptosis in biology and pathology: Resistance to apoptosis in colon carcinogenesis. Ultrastruct. Pathol. 19: 221-248

Payne CM, Bernstein C and Bernstein H (1995b) Apoptosis overview emphasizing the role of oxidative stress, DNA damage and signal-transduction pathways. Leuk. Lymph. 19: 43-93

Payne CM, Bjore Jr CG and Schultz DA (1992) Change in the frequency of apoptosis after low- and high-dose X-irradiation of human lymphocytes. J. Leuk. Biol. 52 $433-440$

Porteous JW, Furneaux HM, Pearson CK, Lake CM and Morrison A (1979) Poly(adenosine diphosphate ribose) synthetase activity in nuclei of dividing and of non-dividing but differentiating intestinal epithelial cells. Biochem. J. 180: $455-463$

Reddy BS, Watanabe K, Weisburger JH and Wynder EL (1977) Promoting effect of bile acids in colon carcinogenesis in germ-free and conventional F344 rats. Cancer Res. 37: 3238-3242

Roberts JH, Stark P, Giri CP and Smulson M (1975) Cytoplasmic poly(ADP-ribose) polymerase during the HeLa cell cycle. Arch. Biochem. Biophys. 171: 305-315

Schreck R, Rieber P and Baeuerle PA (1991) Reactive oxygen intermediates as apparently widely used messengers in the activation of the NF-kappaB transcription factor and HIV-1. EMBO J. 10: 2247-2258 
Shall S (1984) ADP-ribose in DNA repair: a new component of DNA excision repair. Adv. Rad. Biol. 11: 1-69

Sharma HW and Narayanan R (1996) The NF- $\kappa$ B transcription factor in oncogenesis. Anticancer Res. 16: 589-596

Stadler J, Stern HS, Yeung KS, McGuire V, Furrer R, Marcon N and Bruce WR (1988) Effect of high fat consumption on cell proliferation activity of colorectal mucosa and on soluble faecal bile acids. Gut 29: 1326-1331

Todd MD, Lee MJ, Williams JL, Nalezny JM, GeeP, Benjamin MB and Farr SB (1995) The CAT-Tox $(L)$ assay: A sensitive and specific measure of stess-induced transcription in transformed human liver cells. Fund. Appl. Tox. 28: 118-128

Wan XS, Devalaraja MN and St. ClairDK (1994) Molecular structure and organization of the human manganese superoxide dismutase gene. DNA Cell Biol. 13:11271136
Watabe $J$ and Bernstein $H$ (1985) The mutagenicity of bile acids using a fluctuation test. Mutation Res. 158: 45-51

Yoshihara K, Tanigawa Y, Burzio $L$ and Koide SS (1975) Evidence for adenosine diphosphate ribosylation of $\mathrm{Ca}^{2+}, \mathrm{Mg}^{2+}$-dependent endonuclease. Proc. Nat. Acad. Sci. USA 72: 289-293

Zheng Z-Y and Bernstein C (1992) Bile salt/acid induction of DNA damage in bacteria cells: effect of taurine conjugation. Nutrition and Cancer 18: 157-164

Zheng Z-Y, Bernstein H, Bernstein C, Payne CM, Martinez JD and Gerner EW (1996) Bile acid activation of the gadd153 promoter and of $p 53$-independent apoptosis: Relevance to colon cancer. Cell Death Different. 3: 407-414 